Author version: Quat. Sci. Rev., vol.30; 2011; 3871-3879

\title{
Variations of Indian Monsoon Precipitation During the last 32 kyr Reflected in the Surface Hydrography of the Western Bay of Bengal
}

\author{
Pawan Govil $^{1,2}$, P. Divakar Naidu ${ }^{1 * *}$, Henning Kuhnert ${ }^{3}$
}

1. National Institute of Oceanography (Council of Scientific and Industrial Research), Dona Paula, Goa - 403 004. India.

2. Present address: Birbal Sahni Institute of Palaeobotany, 53 University Road, Lucknow - 226007, India.

3. Universität Bremen, Marum, Postfach 330 440, D-28334 Bremen, Germany.

\begin{abstract}
Hydrography of the Bay of Bengal is highly influenced by the river runoff and rainfall during the southwest monsoon. We have reconstructed $\delta^{18} \mathrm{Osw}$, sea surface salinity and sea surface temperature (SST) changes in the Bay of Bengal by using paired measurements of $\delta^{18} \mathrm{O}$ and $\mathrm{Mg} / \mathrm{Ca}$ in a planktonic foraminifera species Globigerinoides ruber from core SK218/1 in the western Bay of Bengal in order to understand the rainfall variability associated with southwest monsoon over the past 32 kyr. Our SST reconstructions reveal that Bay of Bengal was $\sim 3.2^{\circ} \mathrm{C}$ cooler during the LGM as compared to present day temperature and a $\sim 3.5^{\circ} \mathrm{C}$ rise in SST is documented from 17 to $10 \mathrm{ka}$. Both SST and $\delta^{18}$ Osw exhibit greater amplitude fluctuations during MIS 2 which is attributable to the variability of NE monsoon rainfall and associated river discharge into the Bay of Bengal in association with strong seasonal temperature contrast. On set of strengthening phase of SW monsoon was started during Bølling/Allerød as evidenced by the low $\delta^{18} \mathrm{Osw}$ values $\sim 14.7 \mathrm{ka}$. $\delta^{18} \mathrm{Osw}$ show consistently lower values during Holocene (with an exception around $5 \mathrm{ka}$ ), which suggests that the freshening of Bay of Bengal due to heavy precipitation and river discharge caused by strong SW monsoon. Results of this study signify that the maximum fluctuations of the NE monsoon rainfall during MIS 2 appear to be controlled by the strong seasonality and boundary conditions.
\end{abstract}

**corresponding author 


\section{Introduction}

The Indian Ocean monsoon is an important component of global climate that transports heat and moisture from the warmest part of the tropical ocean across the equator to higher latitudes. The seasonal reversal of monsoon winds and associated monsoon rainfall over the Asia has a direct effect on the socio-economic and agricultural development in the densely populated Asian region. Hence, reliable forecasting of monsoon rainfall is an important issue in the Asian sub-continent. To increase the accuracy of monsoon forecasting one need to understand the variability of monsoon rainfall at different time scales from decadal, centennial and millennial time scales.

Several researchers have studied the variability of SW monsoon mainly based on upwelling indices (Prell, 1984; Anderson and Prell, 1993; Naidu and Malmgren, 1996; Overpeck et al., 1996) from the western Arabian Sea where the upwelling occurs during the SW monsoon season. Attempts have also been made to reconstruct monsoon variability and/or precipitation by using the oxygen isotope ratios in foraminifera species from the western Arabian Sea (Sirocko et al., 1991), eastern Arabian Sea (Sarkar et al., 2002; Banakar et al., 2005; Tiwari et al., 2005), the Pakistan Margin (Schulz et al., 1998), and the northern Bay of Bengal (BOB) (Kudrass et al., 2001). More recently, monsoon rainfall has been reconstructed by using $\mathrm{Mg} / \mathrm{Ca}$ and $\delta^{18} \mathrm{O}$ values in selected planktonic foraminifer species from the Andaman Sea (Rashid et al., 2007) and Eastern Arabian Sea (Anand et al., 2008; Govil and Naidu, 2010).

As indicated above, one commonly used proxy of past monsoon variations in the eastern Arabian Sea is $\delta^{18} \mathrm{O}$ of planktonic foraminifera. It is influenced by temperature and the $\delta^{18} \mathrm{O}$ of seawater $\left(\delta^{18} \mathrm{Osw}\right)$, where the latter co-varies with salinity and, on millennial time scales, global ice volume. Existing reconstructions assume minor $\left(<0.5^{\circ} \mathrm{C}\right.$; Sonzogni et al., 1998) temperature variations during the Holocene in the Arabian Sea, and foraminiferal $\delta^{18} \mathrm{O}$ is interpreted to reflect salinity. While the ice effect can be corrected for by subtracting global $\delta^{18} \mathrm{O}$ anomalies (Shackleton, 2000), any true temperature changes go unnoticed and would be interpreted as salinity signals instead. Furthermore, SST changes become potentially significant on pre-Holocene times.

These problems are circumvented by combining foraminiferal $\delta^{18} \mathrm{O}$ with $\mathrm{Mg} / \mathrm{Ca}$. Temperature is derived from $\mathrm{Mg} / \mathrm{Ca}$, which allows the calculation of $\delta^{18}$ Osw (Mashiotta et al., 1999). A minor influence of salinity has been suggested to exist for $\mathrm{Mg} / \mathrm{Ca}$ as well (Nürnberg et al., 1996; Lea et al., 1999; 
Kisakürek et al., 2008), but the magnitude is small (Mg/Ca increases by 5-10\% per salinity unit). While some uncertainty is added to salinity reconstructions, the general pattern of past salinity changes is not affected.

The four major rivers Irrawaddy, Brahmaputra, Ganges and Godavari discharge annually approximately $1.5 \times 10^{12} \mathrm{~m}^{3}$ of fresh water into the BOB (Martin et al., 1981) and are largely responsible for its low salinity (Yaremchuk et al., 2005). Annual rainfall over the BOB varies between $1 \mathrm{~m}$ off the east coast of India to more than 3 m over the Andaman Islands (Baumgartner and Reichel, 1975). The peak discharge of rivers and rainfall over the BOB occurs during the SW monsoon season during June to September, which leads to a strongly stratified near-surface layer and a drop in surface salinity in the order of $4 \mathrm{psu}$ in the northern BOB (Wyrtki, 1973). Therefore, BOB is highly suitable basin to reconstruct the rainfall variation through $\delta^{18} \mathrm{Osw}$ variations in the past. Therefore, we aim at reconstructing variations of the Indian summer monsoon rainfall and concurrent temperature changes in the BOB. Globigerinoides ruber (white) is a surface-dwelling species, lives throughout the year and highest fluxes were noticed during the SW monsoon in the BOB (Guptha et al., 1997). Hence, combined

measurements of $\mathrm{Mg} / \mathrm{Ca}$ and $\delta^{18} \mathrm{O}$ from $G$. ruber were used to reconstruct SST and SSS over the past 32 kyr. This study will provide a high resolution ( $\sim 500$ years) marine perspective of the Indian monsoon in a sparsely studied region.

\section{Surface hydrography of the Bay of Bengal}

The Northern Indian Ocean has two different surface water masses. A low salinity water mass is formed in the BOB by excess precipitation and abundant river runoff. A high salinity water mass is formed in the Arabian Sea due to excess evaporation and the subsurface flow of Persian Gulf and Red Sea water (Wyrtki, 1973). During the SW monsoon high precipitation in the BOB and fresh water discharge from the Ganges, Bramhaputra, Irrawadi and Godavari form a salinity gradient in the BOB, ranging from 26 in the north to 34 psu in the south (Fig. 1a) (Levitus, 1994). Low salinity surface water of BOB moves westward of the south equatorial current during the NE monsoon. Recent studies from BOB have shown a north to south gradient in $\delta^{18}$ Osw that resembles the salinity gradient, with lowest values in the north (-0.5) and highest values in the south (0.5) (Fig. 1b).

During winter SST in the BOB varies from $25.7^{\circ} \mathrm{C}$ in the north to $28.7^{\circ} \mathrm{C}$ in the south (Fig. 2a), whereas, during summer SST varies from $28^{\circ} \mathrm{C}$ in the east to $28.6^{\circ} \mathrm{C}$ in the west (Levitus and Boyer, 1994) (Fig. 2b). 


\section{Material and Methods}

\subsection{Core and chronology}

Core SK218/1 was collected at a water depth of $3307 \mathrm{~m}$ from the BOB (1402'06" lat; $82^{\circ} 00^{\prime} 12$ " long) (Fig. 1a; b). The age model of this core was established based on 8 AMS ${ }^{14} \mathrm{C}$ dates between 0.6 and $36.8 \mathrm{kyr}$ (Fig. 3). AMS ${ }^{14} \mathrm{C}$ dating was performed on mono-specific samples of the planktonic foraminifera G. ruber using the Tandem Accelerator at Leibniz Labor für Altersbestimmung und Isotopenforschung, Christian-Albrechts-Universität, Kiel, Germany and Arizona AMS Facility, Arizona University, Arizona. Radio carbon ages were calibrated to calendar years using the calibration program (CALIB 6.0) of Stuiver and Reimer, (1993). Before calibration, radiocarbon dates were corrected for a reservoir effect (400 years) based on observations from the Indian Ocean (Southon et al., 2002). An age reversal in the uppermost $66 \mathrm{~cm}$ suggests the presence of slumped material from the slope, and this part of the core was discarded for further analyses. From $68 \mathrm{~cm}$ downwards no reworked sediment was deposited at this site as evident from the chronology; therefore, we have developed chronology from the age corresponding to $68 \mathrm{~cm}$ depth of the core. Sedimentation rate varies from 7.08 to $21.66 \mathrm{~cm} / \mathrm{kyr}$ at this core location and sedimentation rates between age control points are shown in figure 3 .

\section{$3.2 \mathrm{Mg} / \mathrm{Ca}$ analyses and estimation of temperature}

For determination of $\mathrm{Mg} / \mathrm{Ca}, 30$ to 40 individuals of planktonic foraminiferal species $G$. ruber (white variety) with a size range of 250 to $350 \mu \mathrm{m}$ were picked and gently crushed while viewed with a binocular microscope. Care was taken not to pulverize broken shell fragments. Clay lumps and shell fragments containing clays were removed manually. Crushed samples were cleaned and dissolved following the protocol described in Barker et al. (2003). $\mathrm{Mg}$ and $\mathrm{Ca}$ analyses were carried out on a Thermo Finnigan Element2 sector field inductively coupled plasma mass spectrometer. Elemental concentrations were derived from the isotopes ${ }^{25} \mathrm{Mg}$ and ${ }^{43} \mathrm{Ca} ;{ }^{89} \mathrm{Y}$ served as internal standard. ${ }^{27} \mathrm{Al}$, and ${ }^{55} \mathrm{Mn}$ were also routinely measured simultaneously to monitor the effectiveness of the cleaning protocol. The analytical error for $\mathrm{Mg} / \mathrm{Ca}$ was better than $0.7 \%$. 40 sample solutions were measured in replicate on different days with repeatability for $\mathrm{Mg} / \mathrm{Ca}$ of $\pm 0.1 \mathrm{mmol} / \mathrm{mol}(1 \sigma)$.

SST was estimated using a relationship obtained from core-tops from the North Atlantic (Dekens et al., 2002): $\mathrm{Mg} / \mathrm{Ca}=0.38 \exp \left(0.09\right.$ (SST)), where $\mathrm{Mg} / \mathrm{Ca}$ is in $\mathrm{mmol} / \mathrm{mol}$ and $\mathrm{SST}$ is in ${ }^{\circ} \mathrm{C}$. This calibration equation was selected because derived temperatures of the core tops were close to modern 
values at the core location, which is within error estimate of $\pm 0.3^{\circ} \mathrm{C}$. We took utmost care in picking the pristine specimens of $G$. ruber for $\mathrm{Mg} / \mathrm{Ca}$ analysis, furthermore, our microscopic examination many other planktonic foraminiferal species which are susceptible to dissolution do not shown any sign of dissolution in this core. Therefore, one can rule out the effect of dissolution on the $\mathrm{Mg} / \mathrm{Ca}$ ratios of $G$. ruber in this core.

\subsection{Oxygen isotope analyses}

For the $\delta^{18} \mathrm{O}$ analyses, new splits of cleaned G. ruber specimens (250 to $350 \mu \mathrm{m}$ size range) were analysed using a Finnigan MAT 252 mass spectrometer equipped with an automatic carbonate preparation device at the Universität Bremen, Germany. The mean external error and reproducibility $(1 \sigma)$ of carbonate standard is better than $\pm 0.07 \%$ and $\pm 0.05 \%$ or $\delta^{18} \mathrm{O}$ and $\delta^{13} \mathrm{C}$, respectively. Oxygen and carbon isotopic values are calibrated against the NBS 18,19 and 20 standards and are expressed as per mil (\%o) versus the Vienna Pee Dee belemnite (VPDB) standard.

\subsection{Estimation of $\delta^{18} \mathrm{Osw}$ from $\mathrm{Mg} / \mathrm{Ca}$ and $\delta^{18} \mathrm{Oc}$}

$\delta^{18} \mathrm{Osw}$ was constructed from $\delta^{18} \mathrm{Oc}$ using temperatures estimated by $\mathrm{Mg} / \mathrm{Ca}$ by applying the following equation of Bemis et al. (1998): $\delta^{18} \mathrm{Osw}=0.27+\left(\left(\mathrm{T}-16.5+4.8^{*} \delta^{18} \mathrm{O}\right) / 4.8\right)$. The derived $\delta^{18} \mathrm{Osw}$ estimates were corrected for continental ice volume using Shackleton (2000) data set. Since no millennial time scale ice volume data is available, to achieve a common time scale both data sets were interpolated to $0.5 \mathrm{ka}$ intervals using a spline interpolation and found no significant difference between splined and original data sets. Based on the analytical errors for $\mathrm{Mg} / \mathrm{Ca}$ and $\delta^{18} \mathrm{Oc}$, an overall error estimate $(1 \sigma)$ for the reconstructed $\delta^{18} \mathrm{Osw}$ is $\pm 0.1 \%$. $\delta^{18}$ Osw values were converted to salinity by using the equation given by Rostek et al. $(1993)$ : $S=\left(\delta^{18}\right.$ Osw +15.2$) / 0.45$. Reconstructing salinity from $\delta^{18} \mathrm{Osw}$ assumes that the isotopic composition and source of precipitation have remained the same over time. Therefore, salinity values should be considered semi-quantitative estimates.

\subsection{Results}

\subsection{Oxygen Isotopes}

The $\delta^{18}$ Oc values range from -3.18 to $-0.67 \%$ over the last $32 \mathrm{kyr}$ at this core location. In MIS 3 , $\delta^{18} \mathrm{Oc}$ values vary from -1.71 to $-1.06 \%$ with an average value of $-1.26 \%$. During MIS $2, \delta^{18}$ Oc values 
ranges from -1.97 to $-0.67 \%$ with an average value of $-1.10 \%$ (Fig. 4 ). $\delta^{18}$ Oc values document two step depleting trend at $16 \mathrm{ka}$ and $11.5 \mathrm{ka}$ with enriched values during YD (Fig. 4).

\subsection{Sea Surface Temperature}

SST reconstructions based on $\mathrm{Mg} / \mathrm{Ca}$ show a temperature range of $29.5^{\circ} \mathrm{C}$ to $25.2^{0} \mathrm{C}$ over the last $32 \mathrm{kyr}$ in the western BOB (Fig. 5). The Western BOB was $\sim 3.2^{0} \mathrm{C}$ cooler during the LGM than the present day. A temperature range of 26.7 to $28.1^{\circ} \mathrm{C}, 25.2$ to $28.2^{\circ} \mathrm{C}$ and 27.1 to $29.5^{0} \mathrm{C}$ was noticed during MIS 3, 2 and 1 respectively. SST reconstructions show a gradual decrease of $3^{0} \mathrm{C}$ from 26 to 17 $\mathrm{ka}$ and gradual increase of $3.5^{\circ} \mathrm{C}$ from 17 to $10 \mathrm{ka}$ at this core location (Fig. 5). During MIS 2 SST varies from 25.2 to $28.2^{\circ} \mathrm{C}$ with two brief warm excursions centered at $\sim 20$ and $\sim 17 \mathrm{ka}$. These anomalies are based on several data points and we exclude the possibility of individual outliers in the $\mathrm{Mg} / \mathrm{Ca}$ record.

\subsection{Oxygen Isotope Ratios of Surface Waters $\left(\delta^{18} \mathrm{Osw}\right)$ and salinity}

$\delta^{18} \mathrm{Osw}$ values range from 0.7 to $0.02 \%$, and 1.05 to $-0.23 \%$ during MIS 3 and MIS 2 respectively. The $\delta^{18}$ Osw variability was higher during MIS 2 as compared to MIS 3 (Fig. 5). Within MIS $2 \delta^{18}$ Osw shows significant fluctuations with enriched values around $20 \mathrm{ka}$ and $17 \mathrm{ka}$, which coincides with timing of warm events (ASW1 and ASW2), reported earlier in the Arabian Sea (Saher et al., 2007; Govil and Naidu, 2010). Between 16.6 and $14.6 \mathrm{ka}$ strikingly a steep excursion of $\delta^{18}$ Osw with $1.4 \%$ depleted values are documented at this site. During MIS1, $\delta^{18} \mathrm{Osw}$ is generally low, but extremely variable over the past $4 \mathrm{ka}$, with values ranging from $0.95 \%$ o to $-0.42 \%$ (Fig. 5 ).

\subsection{Discussion}

Planktonic foraminifer fluxes from sediment trap time series from the BOB document that $G$. ruber lives throughout the year (Guptha et al., 1997). Hence, shell $\mathrm{Mg} / \mathrm{Ca}$ and $\delta^{18} \mathrm{O}$ of G. ruber is expected to provide annual mean SST changes in the BOB. This is reflected in our data, where reconstructed SST is $28.5^{\circ} \mathrm{C}$ on average for the late Holocene (0 to $5.1 \mathrm{kyr}$ ), compared with the instrumental annual mean of $28.4^{\circ} \mathrm{C}$ (Boyer et al., 2006) at the core location.

\subsection{Sea surface temperature changes}

SST reconstructions show a temperature range of $29.5^{\circ} \mathrm{C}$ to $25.2^{0} \mathrm{C}$ over the last $32 \mathrm{ka}$ in the western $\mathrm{BOB}$ with a rise of $3.5^{\circ} \mathrm{C}$ from 17 to $10 \mathrm{ka}$ (Fig. 5). During the LGM SST were $3.2^{\circ} \mathrm{C}$ lower than the present day. SST variations of SK218/1 were compared with other published SST records of RC12-344 (12.46 $\mathrm{N} ; 96.04^{\circ} \mathrm{W}$ ) from the eastern BOB (Rashid et al., 2007) (Fig. 5), which shows similar 
cooling during the LGM based on $\mathrm{Mg} / \mathrm{Ca}$ thermometry. In contrast, the foraminiferal transfer function technique yielded no changes in the BOB SST throughout interglacial and glacial times (Cullen, 1981). However, the present study and other published SST records from the tropical Indian Ocean (Bard et al., 1997; Sonzogni et al., 1998; Naidu and Malmgren, 2005; Rashid et al., 2007) and maps of LGM SST compilations (Barrows and Juggins, 2005) document up to 3 to $4^{\circ} \mathrm{C}$ cooling during the LGM as compared to the Holocene, which strongly supports the growing body of evidence that tropical SST were cooler than originally estimated by CLIMAP (1981) based on transfer function techniques. The compilation of SST estimates based on alkenones show a temperature difference of 0.2 to $2.9^{\circ} \mathrm{C}$ between the present day and LGM in the Indian Ocean (Sonzogni et al., 1998) and suggests that LGM cooling has varied in different regions of the Indian Ocean depending on the local hydrographic changes. Comparison of SST differences between modern day and LGM in the Indian Ocean (Present study, Rashid et al., 2007; Naidu and Malmgren, 2005; Dahl and Oppo, 2006; Anand et al., 2008; Saher et al., 2009; Naidu and Govil, 2010) and Pacific Ocean (CLIMAP, 1981; Prell, 1985; Anderson et al., 1989; Lea et al., 2006) indicates that during the LGM the tropical Pacific Ocean did not cool as much as the tropical Indian Ocean. About $4^{\circ} \mathrm{C}$ cooling of the tropical Indian Ocean during the LGM would have implications on the Intertropical Convergence Zone propagation in the northern hemisphere and associated monsoon rainfall in the southeast Asian region.

The BOB is warmer than the Arabian Sea throughout the year (Wyrtki, 1973), in spite of greater SST in BOB than in the Arabian Sea similar range of cooling has been noticed during LGM in the BOB and the Arabian Sea, suggesting that irrespective of the modern SST trend in general the tropical Indian Ocean was 3 to $4^{\circ} \mathrm{C}$ cooler during LGM as compared to modern day. Both eastern BOB (Andaman Sea) (Rashid et al., 2007) and western BOB exhibit SST of $\sim 25^{\circ} \mathrm{C}$ during the LGM suggesting the absence of a zonal SST gradient within the BOB which is similar to present day.

The last deglacial warming was initiated between 18 and $19 \mathrm{ka}$ in the BOB (Fig. 4) consistent with other deglacial SST records in the tropical Indian Ocean (Naidu and Govil, 2010) and contemporaneous with Antarctic deglaciation (EPICA, 2006). Two conspicuous excursions of SST between 19 and $20 \mathrm{ka}$ with rise of $1.3^{\circ} \mathrm{C}$ and between 17 and $15 \mathrm{ka}$ with a rise of $2^{\circ} \mathrm{C}$ was noticed during MIS 2 (Fig. 5). A $1.4^{\circ} \mathrm{C}$ rise in SST was noticed during the Bølling/Allerød at $14.7 \mathrm{ka}$. A drop in SST $\left(0.8^{\circ} \mathrm{C}\right)$ during the onset of YD event is noticed at this site, however after YD a rise of $1.4^{0} \mathrm{C}$ SST is documented between 11.3 to $10.3 \mathrm{ka}$, which is a very significant warming within $1 \mathrm{ka}$. Likewise, RC12344 SST record (Rashid et al., 2007) from Andaman Sea also shows coherent drop and rise in SST 
during onset and termination of YD (Fig. 5). Both SK218/1 and RC12-344 from BOB and Andaman Sea document $\sim 2.5^{\circ} \mathrm{C}$ fluctuations within in Holocene. Therefore, it is suggested here that without accounting temperature contribution to $\delta^{18}$ Oc it would be difficult to interpret the $\delta^{18}$ Oc values in terms of rainfall variability in the $\mathrm{BOB}$.

\subsection{Variability of the Indian Ocean Monsoon}

Seasonal $\delta^{18}$ Osw and salinity changes at the SK218/1 location (Fig. 4) are strongly controlled by the SW monsoon precipitation and associated river discharge to the BOB. Therefore, reconstructed $\delta^{18}$ Osw variations of SK218/1 reflect rainfall variations of the SW monsoon. $\delta^{18}$ Osw shows higher values $(0.1$ to $1 \%$ o from 32 to $16 \mathrm{ka}$ as compared to modern at this site indicating reduced SW monsoon rainfall (Figure 5). A conspicuous $\delta^{18}$ Osw excursion (1.2\%o) between 15.8 to 12.8 ka represents highest rainfall and river discharge for the duration of $3 \mathrm{ka}$ after the initiation of deglaciation in the BOB, which is consistent with the rainfall maximum in north India from 15 to $13 \mathrm{ka}$ as documented in the speleothem $\delta^{18} \mathrm{O}$ record from Timta Cave (Sinha et al., 2010). Similarly, speleotherm records from Hulu (Wang et al., 2001), Donge (Yuan et al., 2004) caves in China also document heavy rainfall during this time. The coincidence of increase rainfall and rise of insolation after the last glaciation suggest that the primary trigger to initiate the Indian monsoon was the summer solar insolation changes, therefore, $\delta^{18}$ Osw from the BOB also render a support to the link between Indian monsoon and solar insolation. However, solar insolation changes may not account the Indian monsoon rainfall variations at millennial time scale, therefore, coupled ocean and atmospheric process may play main role in forcing the Indian Monsoon behavior at millennial time scale.

$\delta^{18}$ Osw document a decrease of $0.5 \%$ during the YD at this location suggesting that SW monsoon rainfall was reduced. Similarly, $\delta^{18}$ Osw records from cores RC12-344 from the Andaman Sea (Rashid et al., 2007) and SK17 from the eastern Arabian Sea (Anand et al., 2008) and $\delta^{18}$ Oc of KL126 from the northern BOB (Kudrass et al., 2001) reveal weaker SW monsoon rainfall during YD. Speleotherm records from India (Sinha et al., 2005) and China (Wang et al., 2001) also document reduced SW monsoon rainfall during YD. However, the upwelling indices records from the western Arabian Sea do not show reduced upwelling strength during YD (Gupta et al., 2003; Overpeck et al., 1996; Naidu and Malmgren, 1996).

Increased rainfall after $12 \mathrm{kyr}$ is in agreement with previous studies that show strengthening of the SW monsoon commenced between 12 and 11 ka (Sirocko et al., 1993; Naidu and Malmgren, 1996; 
Overpeck et al., 1996; Gasse, 2000; Sinha et al., 2005; Rashid et al., 2007). A somewhat later onset at $10.5 \mathrm{kyr}$ has been inferred from a speleothem record from Oman (Fleitmann et al., 2003). From 12 to 2 ka $\delta^{18}$ Osw indicates maximum rainfall than the modern value, consistent with reconstructed $\delta^{18}$ Osw from the eastern Arabian Sea (Govil and Naidu, 2010). In contrast, upwelling reconstructions based on G. bulloides records from the western Arabian Sea show maximum SW monsoon winds from 10 to 5 ka (Naidu and Malmgren, 1996; Overpeck et al., 1996) with an overall decrease from 8 to 2 ka (Gupta et al., 2003) reflects that SW monsoon wind strength has been in descending phase from 8 ka, however, the $\delta^{18} \mathrm{Osw}$ variations in the present studied core from BOB and another core from the eastern Arabian Sea (Govil and Naidu, 2010) show persistently depleted values from 12 to 3 ka revealing that SW monsoon rain fall was highest during this period, which is in agreement with multi proxies record (Ramesh et al., 2010).

Apparently, there are striking differences at times between the upwelling indices records from the western Arabian Sea and $\delta^{18}$ Osw records from the eastern Arabian Sea and BOB. For example, the greater amplitude fluctuations of $\delta^{18}$ Osw during MIS 2 and reduced rainfall during YD as evident from $\delta^{18}$ Osw records from the eastern Arabian Sea (Anand et al., 2008; Govil and Naidu, 2010) and BOB (Rashid et al., 2007) were not documented in the upwelling indices records from the western Arabian Sea (Naidu and Malmgren, 1996; Overpeck et al., 1996).. Hence, we argue that SW monsoon wind strength and associated upwelling in the western Arabian Sea do not necessarily correspond to the monsoon rainfall over the Indian subcontinent.

\subsection{Abrupt excursions of $\delta^{18}$ Osw during MIS 2}

In general, $\delta^{18}$ Osw displays greater amplitude fluctuations during MIS 2 compared with MIS 3 and MIS 1 (except for the most recent $\sim 2 \mathrm{kyr}$ ) with more prominent abrupt excursions of about $0.4 \%$ and $1.2 \%$ between 18.6 and $17 \mathrm{ka}$ and 15.8 and $12.8 \mathrm{ka}$, respectively (Fig. 5). Similarly, $\delta^{18} \mathrm{Osw}$ record of core RC12-344 from the Andaman Sea (Rashid et al., 2007) and $\delta^{18}$ Oc record of $126 \mathrm{KL}$ from the northern BOB (Kudrass et al., 2001) also displays significant excursions between 16 and $14 \mathrm{ka}$.

Greater amplitude $\delta^{18}$ Osw fluctuations during MIS 2 reflect high variability of evaporation and precipitation in the BOB. Though evaporation was higher during MIS2 than in MIS 1 (Rostek et al., 1993), evaporation alone may not account the $\delta^{18}$ Osw fluctuations noticed during MIS 2 at this site, therefore we attribute the observed $\delta^{18}$ Osw fluctuations to regional freshening from enhanced 
precipitation driven by NE monsoon. In the same way, south China Sea the region dominated by NE winter monsoon also exhibit high amplitude fluctuations of sea surface salinity during MIS 2 (Wang et al., 1999) and wet climate (Sun and Li, 1999). Not only the marine records but also continental based $\delta^{18} \mathrm{O}$ record of stalagmites from China inferred high rainfall during MIS2 caused due to strong East Asian Monsoon (Wang et al., 2001). Thus, the observed $\delta^{18}$ Osw fluctuations in MIS 2 are primarily driven by freshening of the BOB during episodes of enhanced NE monsoon rainfall. Further, greater amplitude fluctuations of $\delta^{18}$ Osw (Fig. 5) during MIS 2 reflect significant variability of NE monsoon which probably controlled by glacial boundary conditions in the Tibet Plateau.

\subsection{SST and $\delta^{18}$ Osw relationship over the last $32 \mathrm{kyr}$ in the BOB}

It has been proposed that convection process of the Indian Ocean is controlled by a threshold SST of about $27.5^{\circ} \mathrm{C}$, above which convection increases as a result, the co-variation between SST and precipitation in the tropical Indian Ocean increased (Gadgil, 2003). In the present study also during MIS 3 and 2 whenever SST are $<27.5^{\circ} \mathrm{C}$, SST peaks coincides with enriched $\delta^{18} \mathrm{Osw}$ indicating weak monsoon rainfall. Whereas, during MIS 1 when SST are $>27.5^{\circ} \mathrm{C}$, overall depleted $\delta^{18}$ Osw are noticed which reveals strong monsoon rainfall. Therefore, we speculate that a threshold SST of $27.5^{\circ} \mathrm{C}$ holds a key to trigger convection process in the BOB. Thus, if the SST of the BOB exceeds $27.5^{\circ} \mathrm{C}$, as a result, the co-variation between SST and precipitation in the tropical Indian Ocean increases. Therefore, a contraction and expansion of the tropical convection region can decrease and increase temperature, respectively in the tropics (Pierrehumbert, 2000). Furthermore, a decrease in Asian monsoon activity during stadials was related to less convective activity in the monsoon regions (Wang et al., 2001), which supports the concept that tropical convection and monsoon strength are related and threshold SST plays an important role. However, more robust millennial $\delta^{18}$ Osw and SST records from different regions of $\mathrm{BOB}$ are needed to test this hypothesis.

Recently, Saher et al. (2007) have discovered two warm events in the Arabian Sea within MIS 2 based on $\mathrm{Mg} / \mathrm{Ca}$ thermometry and termed them Arabian Sea Warm Event 1 (ASW1) and Arabian Sea Warm Event 2 (ASW2). Contemporaneous warm events (termed W1 and W2 by us) are also evident in SK218/1 SST record, where SST was 1 to $2^{\circ} \mathrm{C}$ higher as compared to the MIS 2 minimum. Generally, salinity and SST are inversely correlated, but we observe the opposite pattern for W1 and W2, where salinity is among the highest of the entire record (Fig. 5). Saher et al. (2007) suggested that ASW1 and ASW2 were driven by reduced upwelling in the Arabian Sea. This can be excluded in our record, as the 
core location in the BOB (Fig. 1) is not influenced by upwelling. The mechanism proposed by Saher et al. (2007) involves the exchange of heat through advection by the South Equatorial Current (SEC) and Northeast Madagascar Current (NEMC). An increase in the heat flux, possibly related to the trade wind strength, would have caused the SST rises in the Arabian Sea. The abrupt warming events W1 and W2 occurred not only in the western Arabian Sea, but also documented in the eastern Arabian Sea (Govil and Naidu, 2010) where upwelling does not occur and the influences of SEC and NEMC are minimal. Hence, NEMC and SEC are unlikely to trigger W1 and W2 in the BOB. Here, warming is accompanied by high salinities, suggesting a significantly reduced SW and NE monsoonal rainfall instead. We speculate that a weakening of the SW monsoon winds may have been responsible for the reduction of both rain fall over the BOB and India, and upwelling in the Arabian Sea.

\section{Conclusions}

SST records based on shell $\mathrm{Mg} / \mathrm{Ca}$ records of $G$. ruber show that the BOB was $\sim 3.2^{0} \mathrm{C}$ cooler during LGM than the today. About 3 to $4^{\circ} \mathrm{C}$ cooling of tropical Indian Ocean during LGM would have implication on the Intertropical Convergence Zone propagation in the northern hemisphere and associated monsoon rainfall in the southeast Asian region. Two abrupt warm SST excursions from 20 to $19 \mathrm{ka}$ and 17 to $15 \mathrm{ka}$ were noticed during last glacial period, which would have caused due to variations of strong NE winter monsoon winds in the BOB.

Variability of $\delta^{18} \mathrm{Osw}$ at this site reveals three points: i. High amplitude fluctuations during MIS 2 were due to freshening of $\mathrm{BOB}$ from enhanced precipitation driven by NE monsoon which was controlled by strong seasonality and glacial boundary conditions, ii. A striking increase in SW monsoon rainfall during Bolling/Allerado and decrease in SW monsoon rainfall during YD, and iii. Overall, Holocene document high SW monsoon rainfall with an exception of low rainfall around 5ka.

\section{Acknowledgements}

This work is financially supported by the Ministry of Earth Sciences, Govt. of India and ISRO GBP. We thank Dr. M. Sudhakar, Ministry of Earth Sciences, New Delhi for providing the core samples. Comments from two anonymous reviewers were of considerable help in revising this paper and are greatly appreciated. Pawan Govil thanks Dr. Stefan Mulitza for providing placement during tenure of DAAD fellowship at the Universität Bremen and German Academic Exchange Service for providing short term DAAD fellowship. This is National Institute of Oceanography Contribution...... 


\section{References}

Alley, R.B., Meese. D.A., Shuman, A.J., Gow, A.J., Taylor, K.C., Grootes, P.M., White, J.W.C., Ram, M., Waddington, E.D., Mayewski, P.A., Zielinski, G.A., 1993. Abrupt accumulation increase at the Younger Dryas termination in the GISP2 ice core. Nature 362, 527-529.

Anand, P., Kroon, D., Singh, A. D., Ganeshram, R. S., Ganssen, G., Elderfield, H., 2008. Coupled sea surface temperature-seawater $\mathrm{d} 18 \mathrm{O}$ reconstructions in the Arabian Sea at the millennial scale for the last 35 ka. Paleoceanography 23, PA4207, doi:10.1029/2007PA001564.

Anderson, D.M., Prell, W.L., 1993. A $300 \mathrm{kyr}$ record of upwelling off Oman during the late Quaternary: evidence of the Asian southwest monsoon. Paleoceanography 8, 193-208.

Anderson, D.M., Prell, W.L., Barratt, N.J., 1989. Estimates of sea surface temperature in the Coral Sea at the last glacial maximum. Paleoceanography 4(6), 615-627.

Banakar, V.K., Oba, T., Volvaiker, A.V., Kuramoto, T., Yamamoto, M., Minagawa, M., 2005. A 100,000 years climate history of the Eastern Arabian Sea: Monsoon precipitation and productivity trends. Marine Geology 219, 99-108.

Bard, E., Rostek, F., Sonzogni, C., 1997. Interhemispheric synchrony of the last deglaciation inferred from alkenone palaeothermometry. Nature 385, 707-710.

Barker, S., Greaves. M., Elderfield, H., 2003. A study of cleaning procedures used for foraminiferal $\mathrm{Mg} / \mathrm{Ca}$ paleothermometry. Geochem. Geophys. Geosyst., 4(9), 8407, doi:10.1029/2003GC000559.

Barrows, T.T., Juggins, S., 2005. Sea-surface temperatures around the Australian margin and Indian Ocean during the Last Glacial Maximum. Quaternary Science Reviews 24, 1017-1047.

Baumgartner, A., Reichel, E., 1975. The World Water Balance: Annual Global, Continental and Maritime Precipitation, evaporation and Runoff. Elsevier Sci., New York, 31 charts, pp.179.

Bemis, B. E., Spero, H. J., Bijma, J., Lea D.W., 1998. Reevaluation of the oxygen isoto-pic composition of planktonic foraminifera:Experimental results and revised paleotemperature equations. Paleoceanography 13, 150-160, doi:10.1029/98PA00070.

Boyer, T.P., Antonov, J.I., Garcia, H.E., Johnoon, D.R et al. 2006. World Ocean Database, 2005. In: Levitus, S (ED), NOAA Atlas NESDS 60. US Government Printing Office, Washington, DC, p.190.

CLIMAP Project Members 1981. Seasonal reconstruction of the Earth's surface at the Last Glacial Maximum, Map MC 36, Geol. Soc.of Am., Boulder, Colo.

Cullen, J.L., 1981. Microfossils evidence for changing salinity patterns in the Bay of Bengal over the last 20,000 years. Palogeography Palaeoclimatology Paleoecology 35, 315-356.

Dahl, A.K., Oppo, D.W., 2006. Sea surface temperature pattern reconstructions in the Arabian Sea. Paleoceanograpy 21, PA1014, doi: 10.1029/2005PA001162. 
Dekens, P.S., Lea, D.W., Pak, D.K., Spero, H.J., 2002. Core top calibration of $\mathrm{Mg} / \mathrm{Ca}$ in tropical foraminifera: refining paleo-temperature estimation. Geochem. Geophys. Geosys., 3, 1022. doi:10.1029/2001GC000200.

Delaygue, G., 2000-2 Part of the global seawater delta oxygen-18 database from doi:10.1594/PANGAEA.57954

PANGAEA,

Delaygue, G., Bard, E., Rollion, C., Jouzel, J., Stievenard, M., Duplessy, J, -C., Ganssen, G., 2001. Oxygen isotope/salinity relationship in the northern Indian Ocean. Journal of Geophysical Research 106 (C3), 4565 - 4574.

Duplessy, J.C., 1982. Glacial to interglacial contrast in the northern Indian Ocean. Nature 295, 464498.

Fairbanks, R.G., 1989. A 17,000-year glacio-eustatic sea-level record: influence of glacial melting rates on the Younger Dryas event and deep-ocean circulation. Nature 342, 637-642.

Fleitmann, D., Burns, S. J., Mudelsee, M., Neff, U., Kramers, J., Mangini, A., Matter, A., 2003. Holocene Forcing of the Indian Monsoon Recorded in a Stalagmite from Southern Oman. Science, $300,1737-1739$.

Gadgil, S., 2003. The Indian monsoon and its variability. Annual Review Earth and Planetary Science 31, 429-467.

Gasse, F., 2000. Hydrological changes in the African tropics since the last glacial maximum. Quaternary Science Reviews 19, 189-211.

Govil, P., Naidu, P.D., 2010. Evaporation-precipitation changes in the eastern Arabian Sea for the last 68ka: Implications on monsoon variability. Paleoceanography 25, PA1210. doi:10.1029/2008PA001687.

Gupta, A.K., Anderson, D.M., Overpeck, J.T., 2003. Abrupt changes in the Asian southwest monsoon during the Holocene and their links to the North Atlantic Ocean. Nature 421, 354-356.

Guptha, M.V.S., Curry, W.B., Ittekkot, V., Muralinath, A.S., 1997. Seasonal variation in the flux of Planktic foraminifera: sediment trap results from the Bay of Bengal, Northern Indian Ocean. Journal of Foraminiferal Research 27: 5-19.

Kisakurek, B., Eisenhauer, A., Bohm, F., Garbe-Schonberg, D., Erez, J., 2008. Controls on shell $\mathrm{Mg} / \mathrm{Ca}$ and $\mathrm{Sr} / \mathrm{Ca}$ in cultured planktonic foraminiferan, Globigerinoides ruber (white). Earth Planet. Science Lett., 273(3-4), 260-269. doi:10.1016/j.eps1.2008.06.026.

Kudrass, H.R., Hofmann, A., Doose, H., Emeis, K., Erlenkeuser, H., 2001. Modulation and amplification of climatic changes in the northern hemisphere by the Indian summer monsoon during the past 80 k.y. Geology 29, 63-66. 
Lea, D.W., Mashiotta, T.A., Spero, H.J., 1999. Controls on magnesium and strontium uptake in planktonic foraminifera determined by living culturing. Geochimica et Cosmochimica Acta 63, 2369-2379.

Lea, D.W., Pak, D.K., Belanger, C.L., Spero, H.J., Hall, M.A., Shackleton, N.J., 2006. Paleoclimate history of Galápagos surface waters over the last 135,000 yr. Quaternary Science Reviews 25, 1152-1167. doi:10.1016/j.quascirev.2005.11.010.

Levitus, S., Boyer, T., 1994. World Ocean Atlas 1994, Vol.4, Temperature, US Department of Commerce, Washington, D.C. 99pp.

Levitus, S., Burgett, R., Boyer, T.P., 1994. World Ocean Atlas 1994, Salinity, NOAA Atlas NESDIS, 3, US Department of Commerce, Washington, DC, 99pp.

Martin, J.M., Burton, J.D., Eisma, D., 1981. River inputs to Ocean systems, United Nations Press, Geneva, Switzerland, pp. 384.

Mashiotta, T.A., Lea, D.W., Spero, H.J., 1999. Glacial-interglacial changes in subantarctic sea surface temperature and $\delta 180$-water using foraminiferal Mg. Earth Planet. Sci. Lett. 170(4), 417-432.

Mohtadi, M., Steinke, S., Luckge, A., Groeneveld, J., Hathorne, Ed. C., 2010. Glacial to Holocene surface hydrography of the tropical eastern Indian Ocean. Earth and Planetary Science Letters doi:10.1016.

Naidu, P.D., Malmgren, B.A., 1996. A high-resolution record of late Quaternary upwelling along the Oman Margin, Arabian Sea based on planktonic foraminifera. Paleoceanography 11, 129-140.

Naidu, P. D., Malmgren, B.A., 2005. Seasonal sea surface temperature contrast between the Holocene and last glacial period in the western Arabian Sea (Ocean Drilling Project Site 723A): Modulated by monsoon upwelling, Paleoceanography 20, PA1004. doi:10.1029/2004PA001078.

Naidu, P.D., Govil, P., 2010. A new Evidence on sequence of deglacial warming in the tropical Indian Ocean. Journal of Quaternary Science doi:10.1002/jqs.1392.

Nurnberg, D., Bijma, J., Hemleben, C., 1996. Assessing the reliability of magnesium in foraminiferal calcite as a proxy for water mass temperatures. Geochim. Cosmochim. Acta 60(5), 803-814.

Overpeck, J.T., Anderson, D.M., Trumbore, S., Prell, W., 1996. The southwest Indian monsoon over the last 18,000 years. Climate Dynamics 12, 213-225.

Pierrehumbert, R.T., 2000. Climate change and the tropical Pacific: The sleeping dragon wakes. Proceedings of National Academy of sciences 97, 1355-1358.

Prell, W.L., 1984. Variation of monsoonal upwelling: a response to changing solar radiation. In: Hansen JE, Takahashi T (eds.). Climatic Processes and Climate sensitivity. Am. Geophys. Union, Maurice Ewing Ser., 5, 48-57. 
Prell, W.L., 1985. The stability of low-latitude sea-surface temperature: an evaluation of the CLIMAP reconstruction with emphasis on the positive SST anomalies. Dept. Energy Tech Report TR-025, Washington, DC.

Ramesh, R., Tiwari, M., Chakraborty, S., Mangave, S.R., Yadava, M.G., Sinha, D.K., 2010. Retrieval of south asian monsoon variation during the Holocene from natural climate archives. Current Science, 99, 1770-1786.

Rashid, H., Flower, B.P., Poore, R.Z., Quinn, T.M., 2007. A 25 ka Indian Ocean monsoon variability record from the Andaman Sea. Quaternary Science Reviews 26, 2586 - 2597.

Rostek, F., Ruhland, G., Bassinot, F.C., Muller, P.J., Labeyrie, L.D., Lancelot, Y., Bard, E., 1993. Reconstructing sea surface temperature and salinity using $\delta 18 \mathrm{O}$ and alkenone records. Nature 364, 319-321.

Saher, M.H., Jung, S.J.A., Elderfield, H., Greaves, M.J., Kroon, D., 2007. Sea surface temperatures of the western Arabian Sea during the last deglaciation. Paleoceanography 22, PA2208. doi:10.1029/2006PA001292.

Saher, M.H., Rostek, F., Jung, S.J.A., Bard, E., Schneider, R.R., Greaves, M., Ganssen, G.M., Elderfield, H., Kroon, D., 2009. Western Arabian Sea SST during the penultimate interglacial: A comparison of $\mathrm{U} 37 \mathrm{~K}$ and $\mathrm{Mg} / \mathrm{Ca}$ paleothermometry. Paleoceanography 24, PA2212, doi:10.1029/2007PA001557.

Sarkar, A., Ramesh, R., Somayajulu, B.L.K., Agnihotri, R., Jull, A.J.T., 2000. High resolution Holocene monsoon record from the eastern Arabian Sea. Earth Planet. Sci. Lett. 177, 209-218.

Schulz, H.S., Von Rad, U., Erlenkeuser, H., 1998. Correlation between Arabian Sea and Greenland climate oscillations of the past 110, 000 years. Nature 393, 54- 57.

Shackleton, N.J., 2000. A 100,000 year ice-age cycle identified and found to lag temperature, carbondioxide, and orbital eccentricity. Science 289, 1897-1902.

Sirocko, F., Lange, H., 1991. Clay mineral accumulation rates in the Arabian Sea during the Late Quaternary. Marine Geology 97, 105-119.

Sirocko, F., Sarnthein, M., Erlenkeuser, H., Lange, H., Arnold, M., Duplessy, J.C., 1993. Century scale events in monsoon climate over the past 24,000 years. Nature 364, 322-324.

Sinha, A., Cannariato, K., Stott, L., Li, H.-C., You, C.F., Cheng, H., Edwards, R.L., Singh, I.B., 2005. Variability of southwest Indian summer monsoon precipitation during the Bølling-Allerød. Geology 33, 813-816.

Sonzogni, C., Bard, E., Rostek, F., 1998. Tropical sea-surface temperatures during the last glacial period: a view based on alkenones in Indian Ocean sediments. Quaternary Science Reviews 17, 1185-1201. 
Southon, J., Kashgarian, M., Fontugne, M., Metivier, B., Wyss, Yim W-S., 2002. Marine reservoir corrections for the Indian Ocean and Southeast Asia. Radiocarbon 44, 167-180.

Stuiver, M., Reimer, P. J., 1993. Extended 14C data base and revised CALIB 3.0 14C age calibration program. Radiocarbon 35, 215-230.

Sun, X., Li, X., 1999. A pollen record of the last $37 \mathrm{ka}$ in deep sea core 17940 from the northern slope of the South China Sea. Marine Geology 156, 227-244.

Tiwari, M., Ramesh, R., Somayajulu, B.L.K., Jull, A.J.T., Burr, G.S., 2005. Early deglacial (19-17 ka) strengthening of the northeast monsoon. Geophys. Res. Lett. 32, L19712. doi:10.1029/2005GL024070.

Wang, L., Sarnthein, M., Erlenkeuser., H., Grimalt, J., Grootes, P., Heilig, H., Ivanova, E., Kienast, M., Pelejero, C., Pflaumann, U., 1999. East Asian monsoon climate during the Late Pleistocene: high-resolution sediment records from the South China Sea. Mrine Geology 156, 245-284.

Wang, Y.J., Cheng, H., Edwards, R.L., AN, Z.S., Wu, J.Y., Shen, C.C., Dorale, J.A., 2001. A HighResolution Absolute-dated Late Pleistocene Monsoon record from Hulu Cave, China. Science 294, 2345-2348.

Wyrtki, K., 1973. Physical oceanography of the Indian Ocean. Vol. 3 of Ecological studies: analysis and synthesis. In B. Zeischel, \& S. A. Gerlach (Eds.), Biology of the Indian Ocean (pp. 18-36). London: Chapman and Hall Ltd.

Yaremchuk, M., Yu, Z., McCreary, J., 2005. River discharge into the Bay of Bengal in an inverse ocean model, Geophys. Res. Lett. 32, L16605. doi:10.1029/2005GL023,750.

Yuan, D., Cheng, H., Edwards, R.L., Dykoski, C.A., Kelly, M.J., Zhang, M., Qing, J., Lin, Y., Wang, Y., Wu, J., Dorale, J.A., An, Z., Cai, Y., 2004. Timing, Duration, and Transitions of the Last Interglacial Asian Monsoon. Science 304, 575-578. 
Table 1. Details of Accelerator Mass Spectrometry (AMS) Radiocarbon Ages for the Core SK 218/1

\begin{tabular}{|c|c|c|c|c|}
\hline S.No. & Lab Reference No. & Depth (cm) & ${ }^{14} \mathrm{C}$ Ages (Years BP) & $\begin{array}{l}\text { Calibrated } \\
\text { Calendar Age } \\
\text { (Years) }\end{array}$ \\
\hline 1 & KIA2845-5 & 68 & $1,055+30$ & 300 \\
\hline 2 & AA93880 & 150 & $3,840 \pm 100$ & 3,311 \\
\hline 3 & KIA2844-8 & 266 & $10,400+60$ & 10,976 \\
\hline 4 & KIA2844-7 & 322 & $13,940+90$ & 15,948 \\
\hline 5 & AAS93881 & 350 & $16,410 \pm 100$ & 18,772 \\
\hline 6 & AAS93883 & 498 & $22,100+410$ & 25,478 \\
\hline 7 & AAS93884 & 550 & $29,300 \pm 330$ & 32,822 \\
\hline 8 & KIA2844-6 & 638 & $33060 \pm 780$ & 36,884 \\
\hline
\end{tabular}



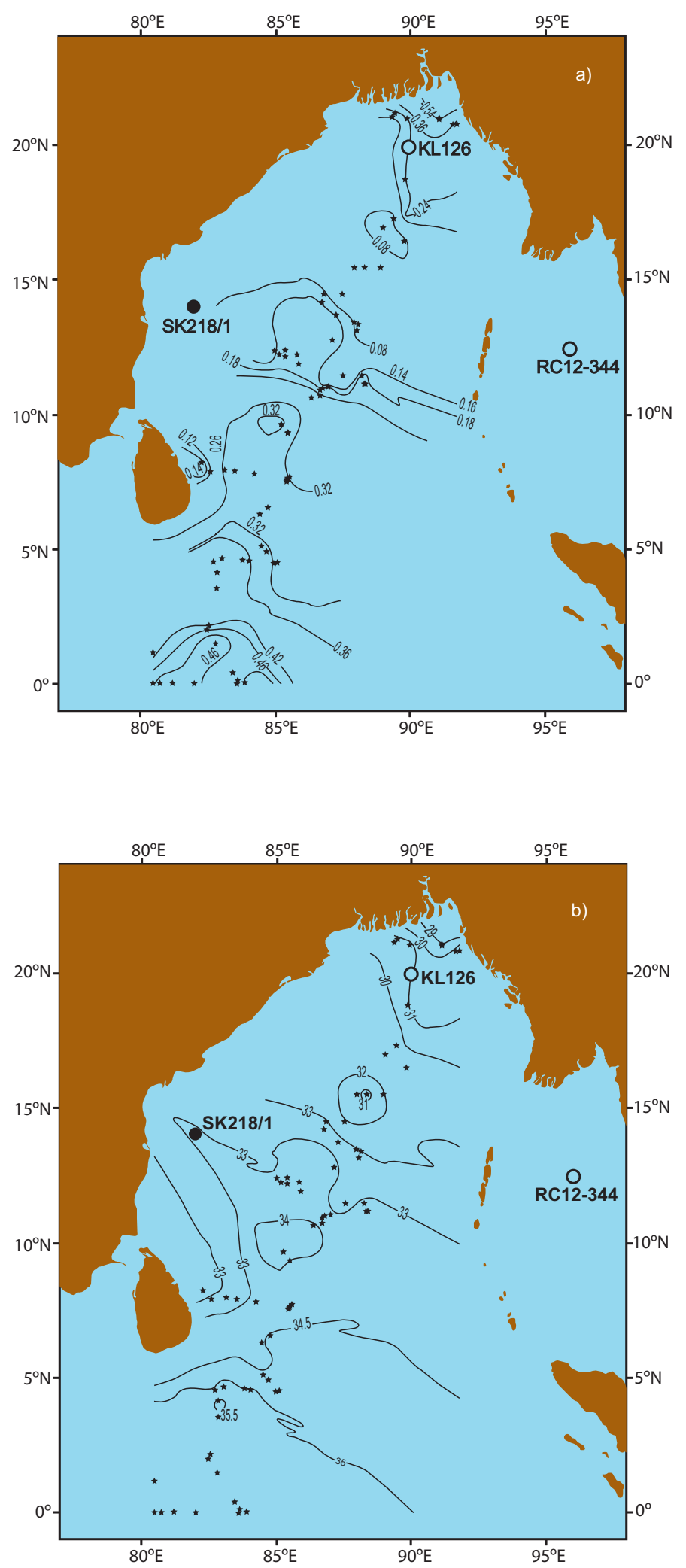

Figure 1. Cores location and sea surface salinity (a) and $\delta^{18} \mathrm{O}$ of sea water (b) during SW monsoon. Salinity and $\delta^{18}$ Osw data is from Delaygue et al., (2001). 


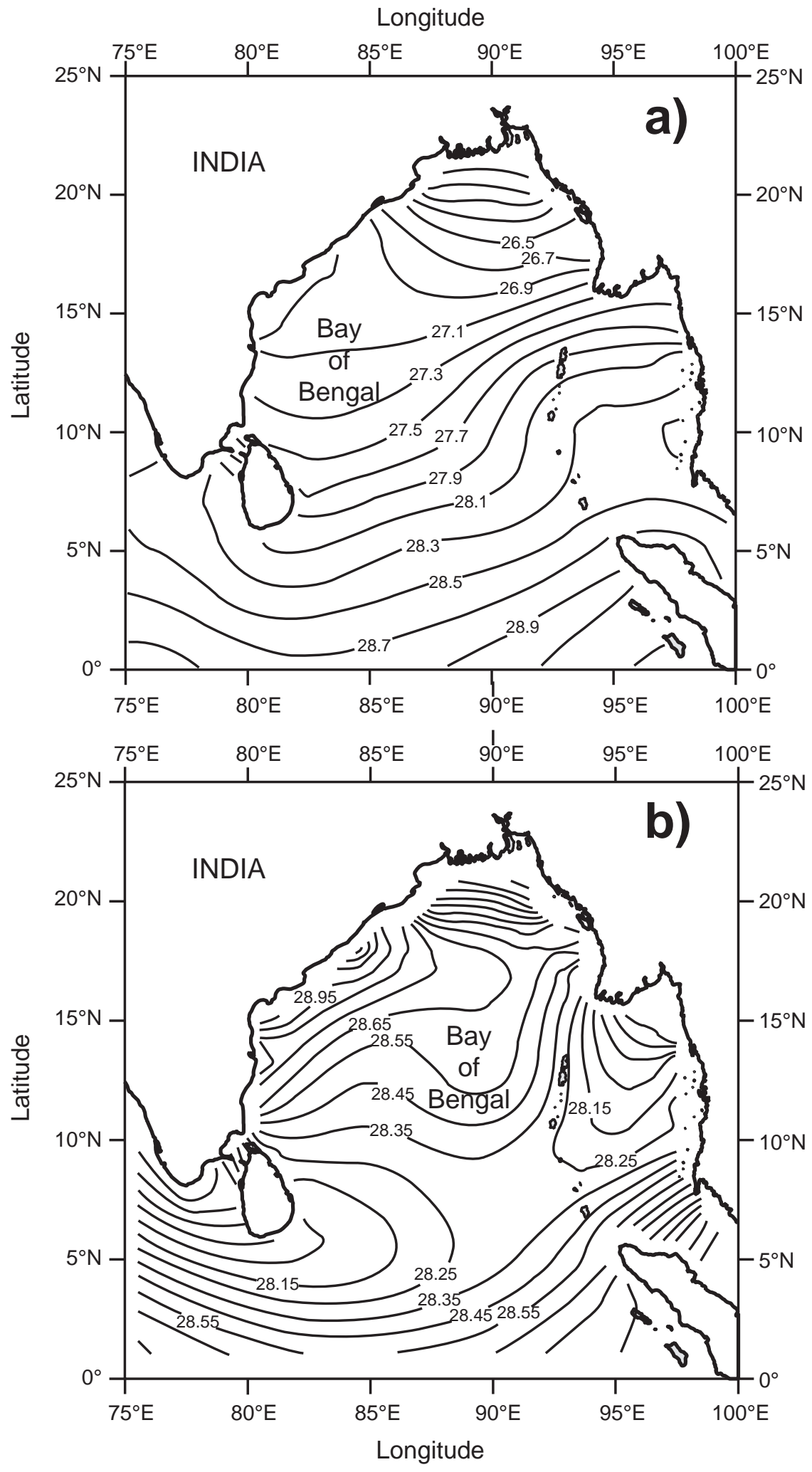

Figure 2. Average sea surface temperature in the Bay of Bengal (a) during the SW monsoon (JuneSeptember) and (b) during NE monsoon (November - February) (Levitus, and Boyer, 1994). 


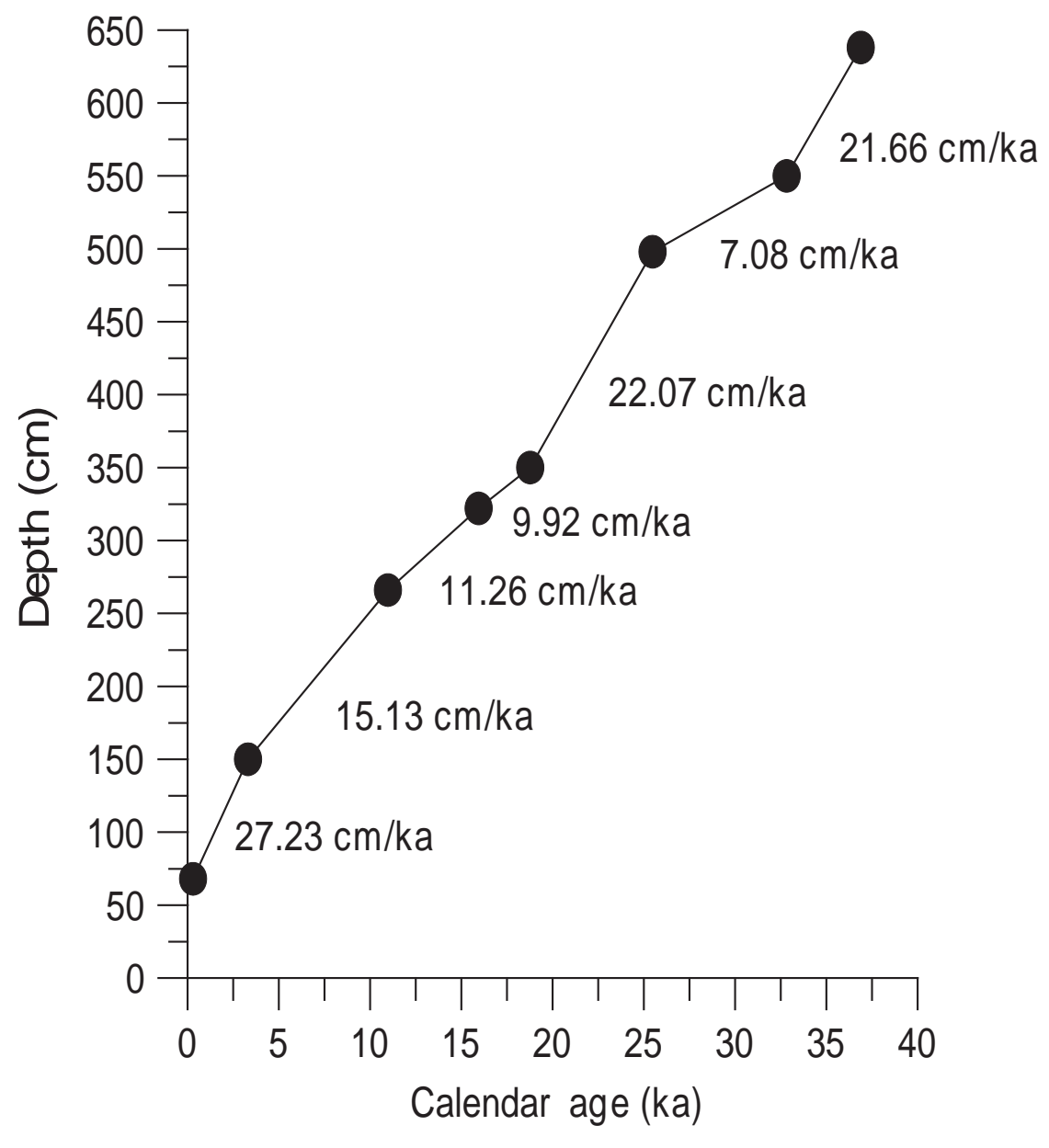

Figure 3. Depth (cm) versus age (kyr BP) and variations of sedimentation rate in the core SK-218/1. $\mathrm{AMS}^{14} \mathrm{C}$ ages are calibrated to calendar years. Though the Core SK218/1 is covered a time span of last $36.8 \mathrm{ka}, \mathrm{Mg} / \mathrm{Ca}$ based SST was reconstructed up to $32 \mathrm{ka}$, hence we limit our discussions on SST and $\delta^{18}$ Osw up to $32 \mathrm{ka}$. 

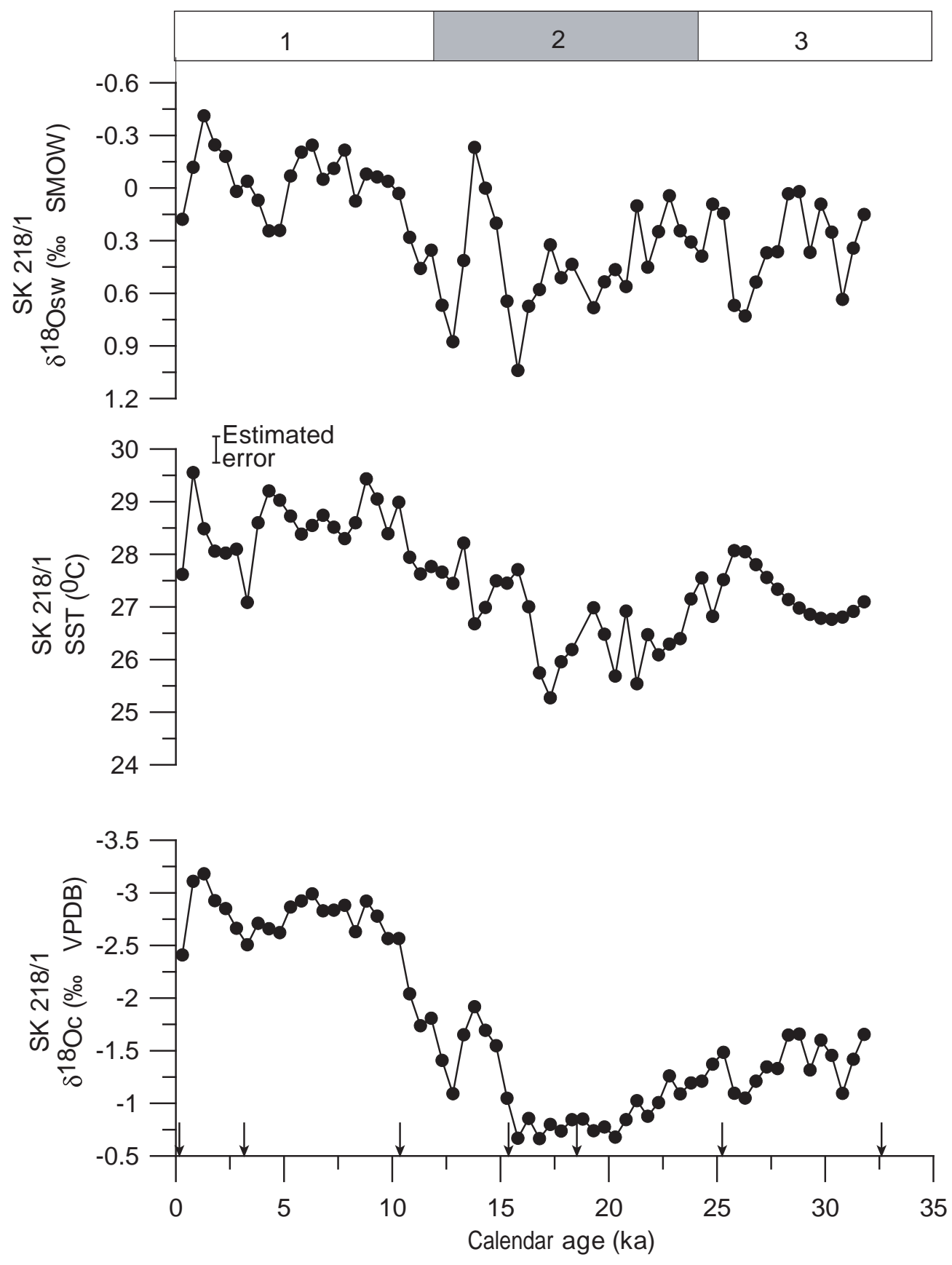

Figure 4: The Oxygen isotope profile of G. ruber $\left(\delta^{18} \mathrm{Oc}\right)$, SST and $\delta^{18} \mathrm{Osw}$ from core SK218/1. $\delta^{18} \mathrm{Osw}$ was calculated using $\delta^{18} \mathrm{Oc}$ and SST derived from $\mathrm{Mg} / \mathrm{Ca}$ and corrected for global ice volume using Shackleton, (2000) data. Arrows pointing to $\mathrm{X}$ axis represent tie points of ages derived from $\mathrm{C}^{14} \mathrm{AMS}$ dates (one ${ }^{14} \mathrm{C}$ AMS date $36.8 \mathrm{ka}$ falls beyond the scale of the above plot hence it is not shown here). 


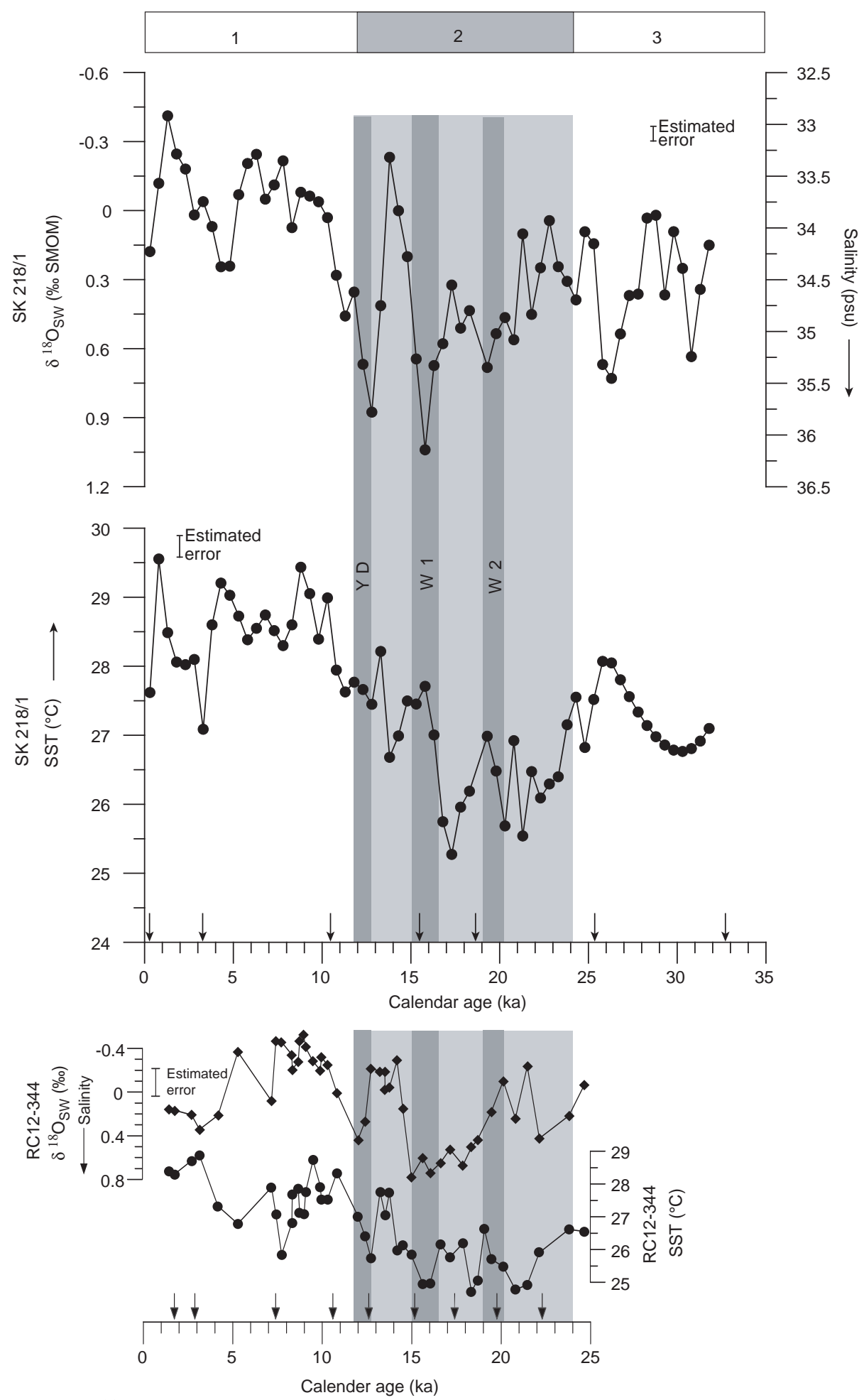

Figure 5. Profiles of $\delta^{18} \mathrm{O}_{\mathrm{SW}}$, salinity and SST in core SK218/1. MIS 2 is shown on grey shade and Younger Dryas (YD) and W1 and W2 are marked with dark bands to show a negative relationship between SST and rainfall (as evident from $\delta^{18} \mathrm{O}_{\mathrm{SW}}$ and salinity) at this site during MIS 2. $\delta^{18} \mathrm{O}_{\mathrm{SW}}$ and SST in cores SK-218/1 are compared with another core (RC12-344) from the Andaman Sea (Rashid et al., 2007). Arrows pointing to $X$ axis represent tie points of ages derived from $C^{14}$ AMS dates (one ${ }^{14} \mathrm{C}$ AMS date 36.8 ka falls beyond the scale of the above plot hence it is not shown here). 